\title{
The Role of Business Education in Restructuring the Fundling of TVET for Sustainable Economic Recovery in Nigeria
}

\author{
Suleiman Lukman ${ }^{1}$, Saidu Mansur Adam ${ }^{1}$, Dahiru Usman Jibrin ${ }^{1} \&$ Buba Umar ${ }^{1}$
}

\begin{abstract}
${ }^{1}$ Department of Vocational and Technology Education, Faculty of Technology Education, Abubakar Tafawa Balewa University, Bauchi,Bauchi State, Nigeria.

Correspondence: Suleiman Lukman, Department of Vocational and Technology Education, Faculty of Technology Education, Abubakar Tafawa Balewa University, Bauchi,Bauchi State, Nigeria, E-mail: luckmansuleimanwase@gmail.com
\end{abstract}

Received: September 13, 2017

Accepted: September 15, 2017

Online Published: September 24, 2017

\begin{abstract}
Over the years different researches have made emphasis on funding TVET, however this research is ambitious on finding the roles played by business education in restructuring the funding of TVET for sustainable economic recovery, in doing that, the concept of business education was discuss by different school of thought, the current status of TVET in the Nigerian context was also explain on how the acquisition of formal technical education is possible from secondary to tertiary levels of the country's 9-3-4 education system. The legacy of under-funding from the past brought the need for providing the policy for restructuring the funding of TVET in the Nigerian system of education. Business education played an important roles in reframing the funding of TVET where ten (10) roles have been pointed out in the research means for restructuring the funding of TVET programme for sustainable economic recovery in Nigeria.
\end{abstract}

Keywords: Business Education, Funding, Technology Vocational Education and Training, Economic Recovery. Introduction

\section{Introduction}

The major challenge facing Nigeria today is slow economic development, prevalence of poverty, and ignorance on how to empower citizens with education that will help them to become self-reliant. The nation is also searching for how best to engage the teeming population of youths in Technology Vocational Education and Training (TVET) skills. Onderi, Ajowi\&Malala (2014) define TVET as an educational programme that involve the study of technologies and sciences in relation to general education, that are supported by acquiring awareness, knowledge, skills and attitudes relating to occupations in various sectors of economic and social life. TVET is one of the essential driving forces and a necessary condition for a country's economic, social and cultural development (Amkombe, 2009). TVET plays such a role as it strengthens and increases the productive and creative capacity of human beings (Aliyu 2013). Business education is the type of education will provide a tools for generating knowledge, raising living standards, and enrichment of educational goals as well as boosting 
The Role of Business Education in Restructuring the Funding of TVET for Sustainable Economic Recovery in Nigeria

the nations' economic activities. However, the funding of TVET in the Nigerian institutions of learning is facing a serious problems, this is because the programme require the development of skills for the production of technocrats and handicrafts men and women that will serve as an engine for sustainable economic growth in Nigeria. Hence, the financing of the TVET programme is quite inadequate, despite the fact that Business Education plays a vital role inTVET funding which is crucial for employability in every nation and serve as the hub for skills provision.

\section{Concept of Business Education}

Business Education is the education for acquisition and development of skills, competencies, attitude and attributes which are necessary for efficiency of the economic system (Aliyu, 2013). It is an intellectual and vocational preparation of people for earning a living in a contemporary industrial and business environment. Adeshina (2007) viewed business education as the training system that encourages the beneficiary to acquire the skills that fit into the world of work. Business education is part of the field of education that deals with business expansion both for specialized occupation uses and for general use (Ouala, 2000). According to Magnus (2007)business education is the aspect of vocational education that provides institutions for the preparation of office occupation such as secretary, typist, book-keeper, data processor, word processorand computer analyst. In a nutshell the term business education has been regarded by many as a mere technology especially in Nigeria.

\section{Current Status of TVET in Nigeria}

TVET varies from one country to another.Technology Vocational Education(TVE) students are trained at different levels in different types of institutions of learning such as polytechnics, enterprises and apprenticeship training centres. In Nigeria, the acquisition of formal technical education is possible from secondary to tertiary levels of the country's 9-3-4 education system. At post-secondary/ tertiary levels, technical and vocational institutions such as polytechnics, monotechnics and universities, have been designed meant to enhance nation's TVET for sustaining and recovering the nation's economy. The duration of school based TVET is between three to five years, depending on the nature of the institution and model. However, formal TVET in Nigeria are currently operating in environment that is characterized by inadequate financing, andit must be recognized that TVET is expensive which as a result many students will not be able to afford the required training materials without support from government and or to find a way on how the programme will finance itself during the training process(Adhiambo, 2015). Even though subvention to training institutions particularly polytechnics has been increased and government support also increased due to the tireless effort of Tertiary Education Trust Fund (TETFund), Educational Trust Fund (ETF) and so forth. It is still grossly inadequate because unit costs are necessarily higher in TVET institutions due to the expensive training equipment and costly training materials that are wasted during practical lessons (Amodu, 2011).

\section{Policy for Restructuring the Funding of TVET}

One of the common complaints from those working in TVE system is lack of suitable equipment or poor facilities, and legacy of under-funding from the past. Since then and even now there was no separately defined budgets for TVET, despite the substantial increase in the budget allocated to the education sector, TVET is still inadequate to meet the required demand. As a sequence many of the TVET are unable to purchase the necessary materials and equipment to deliver quality TVET programs. Hence, improved facilities are more than just increase level of funding, attention has to be given tolacking issues such as how resources are allocated, managed and utilized, and more needs to be done to identify cost recovery strategies and what can be done to raise revenue level in a suitable manner. 
TVET programme shouldbeflexible to the changing demand in the labour market by applying new training technologies and provide opportunities for employees to engage in continuous professional development, life-long learning and emerging new training programs such as business education. This will make TVET an important form of education which triggers a discussion on whether the current internal financing made by government is sustainable and other types of financing should be considered or not.

The possibility of cost sharing with those who benefit from TVET (employers, trainees and their families or the society at large) will have to be considered by the government. Under this TVET policy, funding mechanism are being examined either unilaterally oriented (financed by one stakeholder i.e state, trainee, employer) or are based on co-financing/cost sharing model (e.g apprenticeship programs, dual programs, employer training incentives scheme) this will lead to a funding mechanism of TVET that is both innovative and sustainable (Okwelle, 2015).

\section{Roles of Business Education in Funding TVET in Nigeria}

According to Okolocha (2012) the roles of business education in funding TVET in the Nigerian institutions of learning are as follows:

- Business education helps to expand access in generating fund in the Nigerian institution of learning in the area of TVET training and certification.

- It provides flexible training for crafts-men and women that enables both full-time and part-time participation in which utilization of acquired skills could accumulated the revenue generated over time.

- It upgrades the existing workforce by admitting more trainees that serves as a key tools for poverty eradication and national development.

- It provides work-based learning experiences and strengthen career awareness which in turn mitigate the rate of unemployment in the country.

- It helps schools in building success-oriented colleges and career cultures that empower students' creativity and innovation.

- It helps educators align curriculum and readiness standards with business needs that attract students to look for admission into the TVET programme.

- It provides equipment and financial assistance to modernize classrooms, workspaces, and laboratories.

- It provides financial guidance and advice that minimizes unaffordability of students as a barrier to TVET programme.

- It trains and imparts the necessary skills that leads to the production of craftsmen, technicians and other skilled personnel that became enterprise and self-employed that enhanced the competitiveness of firms and to improve productivity

- It enables our young men and women in obtaining the required technological skills and qualification needed in the work force.

To restructure the role of business education TVET funding system will better address the students' training needs which will serve as a driving force for improving skills acquired and enhanced employability (Okolocha2012). Continued emphasis on financing "soft skills" in training programs through a strategy ofintegration of employability concepts into the teaching and learning process will help in restructuring the TVET programme (Afeti, 2015). It will be very important for all business education unit in the country to enact a policy by making it mandatory for all business education students to put into practice the skills they have acquire before graduation so that creativity and revenue generation will enhanced.Afeti (2015)further said that, 
The Role of Business Education in Restructuring the Funding of TVET for Sustainable Economic Recovery in Nigeria

the major challenge facing TVET in Nigeria is the inadequate financing of the programme by government which as a result creates mismatch between skills, knowledge and attitudes acquired by the learners. Sharing a similar view, Tilak (2003) said that government need to increase funding to support the sector, while educational institutions need to utilize the resources that is been allocated to them to deliver flexible and demand driven training and employers need to contribute to the development of national skills standards. Government should support development of national TVET policies and strategies, capacity building in TVET sector, identifying and disseminating best practices in TVET and encourage TVET advocacy initiatives by Funding TVET research and advocacy (Okolocha, 2012). However, it must be accentuated that acquisition of skills is not sufficient to bring economic development, it is a prerequisite, but a lot more needs to be executed by eradicating poor governance, poor economic policy, corruption, and adequate financial support and infrastructural facilities must have to be put in place before the much needed economic development can be achieved. This can actually reduce the efficiency of the job market in absorbing and producing quality graduates which consequently affect the nations' economic recovery.

There is urgent need to ensure the vision of TVET of inclusive and quality education for all that promote life-long learning needed for all women and men for inculcating affordable and quality technical and vocational training in the Nigerian tertiary education.Hence, adequate financial support is not accompanied with the training programme (Kamau, 2013). Moreover, the non-formal TVET in Nigeria that is imparted to young boys and girls by self-employed artisans and technicians is pervasive. Ajibola andJumoke, (2012) reiterated that, achieving sustainable economic development through technical and vocational education and training requires collective and serious efforts and strong commitments to financing and supporting the artisan and technicians on the part of parents/guardians, educational institutions/training providers, employers and government. Parents should support their children to choose and finance their vocational training and reject the perception that TVET is for less academically endowed.

TVET has fuelled the engine of economic growth and productivity in Nigeria and other western industrialised nations. As markets become increasingly an avenue for global competitiveness, governments are intensifying pressure on national TVET systems to produce more highly skilled and employable workers, this can only be achieved through sustainability and visionary policiesthat gives more attention to funding of TVET programs (Okolocha, 2012). Therefore, Nigeria as a nation will have to empower TVET and must make specific contribution to the implementation of new policy relating to funding of TVET programs and or research and development that willsupported the way on how to effectively finance the TVET programs.

Moreover,Ambuke (2009) said that financing TVET could be the best weapons for fighting poverty and the numerous associated vices plaguing the nation's productive and self-employment. This will give rise to the quality and needed skills that will help the teeming youths to become self-reliant and also mitigate the over dependence on government.

According to Gill and Fluitman (2005) there is an urgent need to restructure TVET programmes which should be geared towards meeting the market demands.Kamau (2013) said that the funding should primarily focus on the knowledge and skills required for industrial development. In a similar view. Harrison and Reddan (2010) said that TVET should therefore be in line with the needs and demands of the current industrial development needs. Ladipo (2013) emphasized that governments should be one of the key element that have to intervene in the funding of TVET programs and also encourage and mobilize stakeholders to invest their resources in TVET for nation's economic growth and development. He further stressed that there is need for cooperation between 
government and various stakeholders to build strong technical and financial support towards reconstruction process and reforms of TVET. This can only be done through proper funding of the training programme that ensure quality delivery, employability of trainees, improve consistency and management of its training and should promote life-long learning so as to make it more attractive to the youths. Adequate training tools and equipment such as textbooks and training manuals must have to be provided, qualified instructors with experience on training the trainees must have to be adequately remunerated, this will go a long way in enhancing the quality delivery in TVET (Maliranta, Nurmi\& Virtanen, 2010).

Wairimu (2009) said that, trainers should be assured of their compensation package before they start training the TVE trainees, this will help in providing quality TVET which might ensures acquisition of skills that are related to the demands of the current labour market. Harrison andReddan (2010) said that governments should establish monitoring agencies for TVET under the ministries of education or as autonomous bodies which should coordinate the training activities of TVET on how the funds are been utilized, these bodies should have representation from all pertinent stakeholders, including policy makers in education, public and private training providers, civil society organizations and development partners, in compensating their efforts allowances should be provided to them as a motivating factor.According to Amodu (2011) The TVET levy has functioned to provide a stable and predictable basisto assure financing for the training and has enabled the development of astrong national training infrastructure for the nation's economic growth, development and recovery. These targets encourage a vision of TVET that supports the transition towards inclusive and sustainable societies and economies. The vision also means that TVET systems will need to develop, transform and adapt to remain relevant, despite the priority displayed by the nation and the international community to skills development, TVET remains largely underfinanced (United Nation, 2017)

\section{Conclusion}

TVET is one of the key element in nation's economic development and growth, the role of business education in funding TVET will never be over emphasize, this is because business education has contributed a lot in restructuring the funding of TVET programs. It is very important for all business education units in the country to enact a policy by making it mandatory for all business education students to put into practice the skills they have acquired before graduation so that creativity and revenue generation will be enhanced.It must be accentuated however that,the acquisition of skills is not sufficient to bring economic development, it is a prerequisite, but a lot more needs to be executed in funding TVET by eradicating poor governance, poor economic policy, corruption, and adequate financial support.

Infrastructural facilities must have be to put in place before the much needed economic development can be achieved through revitalizing the TVET programme. This can actually reduce the efficiency of the job market in absorbing and producing quality graduates which consequently affect the nations' economic recovery. Parents should support their children to choose and finance their vocational training and reject the perception that TVET is for less academically endowed. Therefore, Nigeria as a nation will have to empower TVET and must make specific contribution to the implementation of new policy relating to funding of the programs and or research and development that willsupported the way on how to effectively financed the TVET programs have to be carried out and secured in a qualified manner. Financing TVET will give rise to the quality and needed skills that will help the teeming youths to become self-reliant and also mitigate the over dependence on government.

\section{Recommendation}

The following recommendations were made: 
The Role of Business Education in Restructuring the Funding of TVET for Sustainable Economic Recovery in Nigeria

- Government should increase its spending on education and training.

- Government should reduce tuition and other fees of the training programme to attract more trainees.

- Government should ensure that private enterprises pay for TVET programme

- Government should provide incentives to private TVET providers

- Attention should be given tolacking issues such as how resources are allocated, managed and utilized, and more needs to be done to identify cost recovery strategies on how to raise revenue in a suitable manner.

- TVET programme shouldbe flexible to the changing demand in the labour market by applying new training technologies and provide opportunities for employees to engage in continuous professional development and life-long learning.

\section{References}

Adeshina, T. J. (2007). Understanding Business Education. Esonaji Publishers, Micsons Press Zaria.

Adhiambo, O. M. (2015). Institutional Factors Influencing Participation of Trainers in Public Technical Vocational Education and Training Institutes in Kinango Sub-Ccountry, Kwale, Kenya. Journal of Education and Learning,, Research Thiesis in Press.

Afeti, G. (2015). Technical and Vocational Education and Training for Industrialization. Africa Research and Resource Forum, African Development Bank Group (2014)

Akhuemonkhan, I. A., \&Raimi, L. (2013). Impact of Quality Assurance on Technical Vocational Education and Training (TVET). In Nigeria. Las Vegas, Nevada, United State, African Development Bank Group (2014)

Aliyu, M. M. (2013). Business Education in Nigeria, Trends and Issues, Revised Edition.

Amkombe. K (2009). Technical, Vocational Education and Training as a Tool for Sustainable Development. $A$ synthesis of case studies. Dakar: UNESCO, 76-77.

Amodu, T. (2011). Revamping Our National Economy through Technical Vocational Education and Training (TVET). Available: http: //www.nigerianbestforum.com/blog (Accessed:28 July, 2017).

Gill U, \&Fluitman J. (2005). Vocational education and training reform. Matching skills to markets and budgets, New York: Oxford university press.

Kamau, S. M. (2013). Challenges Affecting the Technical and Vocational Education Training Youths Polytechnics in Kiambu County. International Journal of SocialSciences and Entrepreneurship,, 1(5), 679-687.

Ladipo, M. K. (2013). Technical Vocational Education and Training (TVET) as Mechanism for Sustainable Development in Nigeria (SD): Banjul conference.

Magnus, U. (2007). The Meaning and Objectives of BusinessEducation, Retrieved 24/04/2017 from World Wide Web. http://associate dcontent.com/article.

Maliranta, M., Nurmi, S., \& Virtanen, H. (2010). Resources in Vocational Education and Post-Schooling Outcomes. International Journal of Manpower, 3(5), 520.

Okolocha, C. C. (2012). Vocational Technical Education in Nigeria: Challenges and the Way Forward. Business Management Dynamics,, 2(6), Organization for Economic \& Co-operation Development [OECD]. (2006). Policy framework for investment. A review of good practices. 
The Role of Business Education in Restructuring the Funding of TVET for Sustainable Economic Recovery in Nigeria

Okwelle, S., C. . (2015). Towards Quality Technical, Vocational, Education and Training Programmes in Nigeria. Journal of Education and Learning, 1(4), 21-34.

Onderi H, J, Ajowi, A. P., \&Malala, G. (2014). Restructuring Technical and Vocational Education and Training (TVET) For Sustainable Development in Sub-Saharan Africa International Journal of Interdisciplinary Research and Innovations, 2(1), 40-45.

Ouala, E. C. (2000). a handbook on Vocational Technical Education for Nigeria. UrowiluObasi, Pacific Publisher.

Tilak, J. (2003). Vocational education and training in Asia. Journal of Educational Planning and Administration, 17(1), 1-16.

UNESCO. (2017). Financing Technical and Vocational Education Training UN Campus Platz Der Vereinten Nationen

Wairimu, G. (2009). Significance of Technical, Vocational Education and Training in Africa. (1), Africa Dakar Conference, Dakar: KM Africa .Post Basic Education Training

\section{Copyrights}

Copyright for this article is retained by the author(s), with first publication rights granted to the journal. 